\title{
The City as an Experimental Environment: The Identification, Selection, and Activation of Distributed Knowledge in Regional Open Innovation Ecosystems
}

\author{
Ben Robaeyst ${ }^{1, *}$, Bastiaan Baccarne ${ }^{2} \mathbb{D}$, Wout Duthoo ${ }^{3}$ and Dimitri Schuurman ${ }^{3}$ \\ 1 imec-mict-UGent, Department of Communication Sciences, Ghent University, 9000 Gent, Belgium \\ 2 imec-mict-UGent, Department of Industrial Systems Engineering and Product Design, Ghent University, \\ 9000 Gent, Belgium; Bastiaan.Baccarne@ugent.be \\ 3 imec, Ghent, 9000 Gent, Belgium; Wout.duthoo@imec.be (W.D.); Dimitri.schuurman@imec.be (D.S.) \\ * Correspondence: Ben.robaeyst@ugent.be; Tel.: +32-496-30-14-71
}

\section{check for} updates

Citation: Robaeyst, B.; Baccarne, B.; Duthoo, W.; Schuurman, D. The City as an Experimental Environment: The Identification, Selection, and Activation of Distributed Knowledge in Regional Open Innovation Ecosystems. Sustainability 2021, 13, 6954. https://doi.org/10.3390/ su13126954

Academic Editor: Manuel Duarte Pinheiro

Received: 28 April 2021

Accepted: 14 June 2021

Published: 21 June 2021

Publisher's Note: MDPI stays neutral with regard to jurisdictional claims in published maps and institutional affiliations.

Copyright: (c) 2021 by the authors. Licensee MDPI, Basel, Switzerland. This article is an open access article distributed under the terms and conditions of the Creative Commons Attribution (CC BY) license (https:/ / creativecommons.org/licenses/by/ $4.0 /)$.

\begin{abstract}
Over the past decade, open innovation (OI) literature has extended its scope beyond strictly economic contexts to the context of societal value creation. This has given rise to the notion of (local) distributed knowledge as a driver for sustainable innovation and has highlighted the importance of multi-stakeholder collaborations in new product development (NPD) processes to develop new ICT systems for complex urban issues. Several studies have discussed sustainable stakeholder ecosystem architectures for such collaborations. However, little is known about stakeholder identification and selection processes for collaborations in the urban environment. By combining action research with a case study design, this paper studies the nature of contextualized interactions between knowledge actors in the ecosystem and the processes of attraction, identification, selection, and activation of stakeholders in an urban living lab (ULL). These insights converge in the development of a 'stakeholder acupuncture framework', which structures mechanisms and practices within dynamic collaboration ecosystems and defines key boundary conditions for such open-ended ecosystems.
\end{abstract}

Keywords: open innovation; quadruple helix; distributed knowledge; innovation systems; urban innovation; smart cities; urban living labs; urban acupuncture

\section{Introduction}

Henry Chesbrough [1] introduced the open innovation (OI) concept as a model for organizing technological innovation and argued that firms should make use of internal and external ideas, as well as internal and external paths to market, in order to advance their technologies. Further studies have pointed out that participating in such collaborations or OI networks has multiple beneficial returns for a firm's innovative performance (e.g., for new product development processes, for increasing patent rates, and for improving existing products) [2-8]. Over the last decade, this concept has expanded beyond strictly economic and business applications to include societal value creation. As such, OI has evolved into a common strategy to tackle 'wicked' societal challenges that can only be addressed through (intense) collaboration between diverse actors and domains [9-11]. In particular, cities all over the world face complex challenges regarding population growth, aging, climate change, and public transport. Hence, the pressure on urban areas to be drivers for societal change and accelerated innovation is systematically increasing [12]. In order to tackle these 'wicked' problems, following the 'design science paradigm' [13], recent technological evolutions have fostered a belief in the positive effects of ICT and other innovative technologies in urban areas. The combination of smart (technology enabled) solutions to meet the grand societal challenges and the focus on the city as the main driver of change led to the concept of the 'smart city' [14]. Therefore, 'social open innovation' $[8,15]$, which expands this OI business perspective and aims to facilitate "ideas, 
activities and processes that support the development of new social solutions (products or services), through the inflows and outflows of knowledge and technologies (inbound and outbound activities) and collaboration between different entities (coupled processes), mobilizing actions across boundaries and exploiting ecosystems" [16], can help facilitate solutions for these complex societal challenges.

Because of its correlation with the notion of generative growth [17] and its ability to blur the lines between public and private sectors [18], this paper considers social OI within the regional ecosystem of an urban environment and approaches such ecosystems in accordance with the 'quadruple innovation framework' [7,19]. This framework envisions frameworks as "eco-systemic agglomerations of organizational and institutional entities or stakeholders with socio-technical, socio-economic, and socio-political conflicting as well as converging (co-opetitive) goals, priorities, expectations, and behaviors that they pursue via entrepreneurial development, exploration, exploitation, and deployment actions, and interactions" [10]. In addition, such stakeholders represent a variety of 'assets' (knowledge, infrastructure, financial resources, etc.) which are distributed within the regional space [20]. Benefiting this variety of assets, knowledge assets in particular [21] are considered to be the main driver of regional innovation [17,22]. However, literature shows that this transfer of knowledge assets among entities is often stalled by a lack of ability to transfer innovations and knowledge among entities [16,23,24]. Therefore, identifying, selecting, and activating such assets are important aspects in the sustainable development of innovative urban ICT for complex societal challenges.

Different frameworks have been developed to position social OI in relation to market OI (SMEs and start-ups) and closed OI (big businesses, the macro-dynamics of OI [7,25], and also the micro-dynamics of OI, which includes the application of social OI [26] at the level of the ecosystem (e.g., the quadruple helix innovation framework [19]), the level of the process (e.g., urban living lab literature [27]), and the level of the user (e.g., user innovation [28]). However, the processes and practices used to attract and activate the appropriate stakeholders within multi-stakeholder open innovation collaboration have not been thoroughly studied. In addition, studies have pointed out that the value of partnerships in 'smart city' projects depends on the city council's ability to facilitate and manage these projects since cities have different institutional contexts $[29,30]$. Hence, this paper builds upon these findings, in line with Carayannis and colleagues, and argues that regional ecosystems have their own context of stakeholders who each possess their own set of assets which are useful for regional ICT development [22]. In addition, OI collaboration ecosystems have a wide variety of topic-specific orientations. Consequently, the participating stakeholders in regional NPD processes are assumed to be a good fit for the OI projects that they are affiliated with, in that they enable access to the right assets from the regional innovation ecosystem. This has encouraged researchers to develop frameworks that aid in the identification and activation of the appropriate stakeholders for new urban media development [31]. However, these frameworks do not discuss the specific context of regional innovation ecosystems nor their project-oriented nature. For example, Leminen and Westerlund [32] developed a typology of stakeholder roles in living labs, but this framework does not address the dynamic processes of finding, attracting, and activating these stakeholders (within the context of a regional ecosystem). In addition, Huang et al. [33] emphasizes the importance of the innovation environment which directly determines the innovation efficiency and collaborative participation degree of the industryuniversity research strategy.

Consequently, this study situates focuses on micro-dynamics of open innovation [7] within the context of social open innovation (as opposed to closed open innovation and market open innovation) within a regional innovation ecosystem in a quadruple helix context. More concretely, this paper addresses the gap in research literature by exploring and influencing dynamic ecosystem processes of identification (finding), attraction, and activation of collaborative actors within a concrete quadruple helix setting. By examining a case study, which took on the form of a project that aims to tackle "loneliness with elderly 
citizens", this work provides three main contributions. First, we analyze the identification, attraction, and activation processes for stakeholders in an OI project within a regional innovation ecosystem in a thorough and detailed manner. Second, we develop a framework that structures such processes and can be applied by local policy makers and practitioners when initiating OI projects in the context of an urban living lab. Third, we formulate specific recommendations in order to improve these processes based on this analysis and the developed framework.

\section{Research Framework}

\subsection{Regional Open Innovation Networks}

Building on Chesbrough's [1] definition, subsequent research has described OI as an intense co-development model involving users and other stakeholders, which results in more successful and sustainable innovations [18,34-37] with an increased focus on regional innovation networks [38]. Such regional innovation networks can be defined as inter-organizational networks formed by heterogeneous actors that originate from the same geographical area and collaborate in NPD processes in a long-term informal manner [33,38-40]. In line with Carayannis and colleagues [19], we interpret regional innovation networks as local networks of stakeholders who can be divided into four helices: governmental actors, economical actors, knowledge actors, and civilian actors. Such networks are described as fractal, multi-level, multi-modal, and multi-lateral configurations of dynamic tangible and intangible assets [19,41]. These assets include individuals' skills, the relationships between key regional stakeholders, and the formal mechanisms in place to support regional knowledge creation. In addition, Lönqvist and colleagues [22] argue that such assets act as drivers for regional innovation, but they are distributed throughout the network. We consider regional open innovation ecosystems to be networks that are in a constant state of flux, with stakeholders that possess assets and mutually interact within the network. We apply the network of networks theory to conceptualize the regional ecosystem. This describes the ecosystem as a network of multiple heterogeneous networks, with varying actor interdependencies [42]. Given that knowledge is shared in social innovation networks through processes of social interaction [43], the regional open innovation network can be conceptualized and visualized as follows (Figure 1).

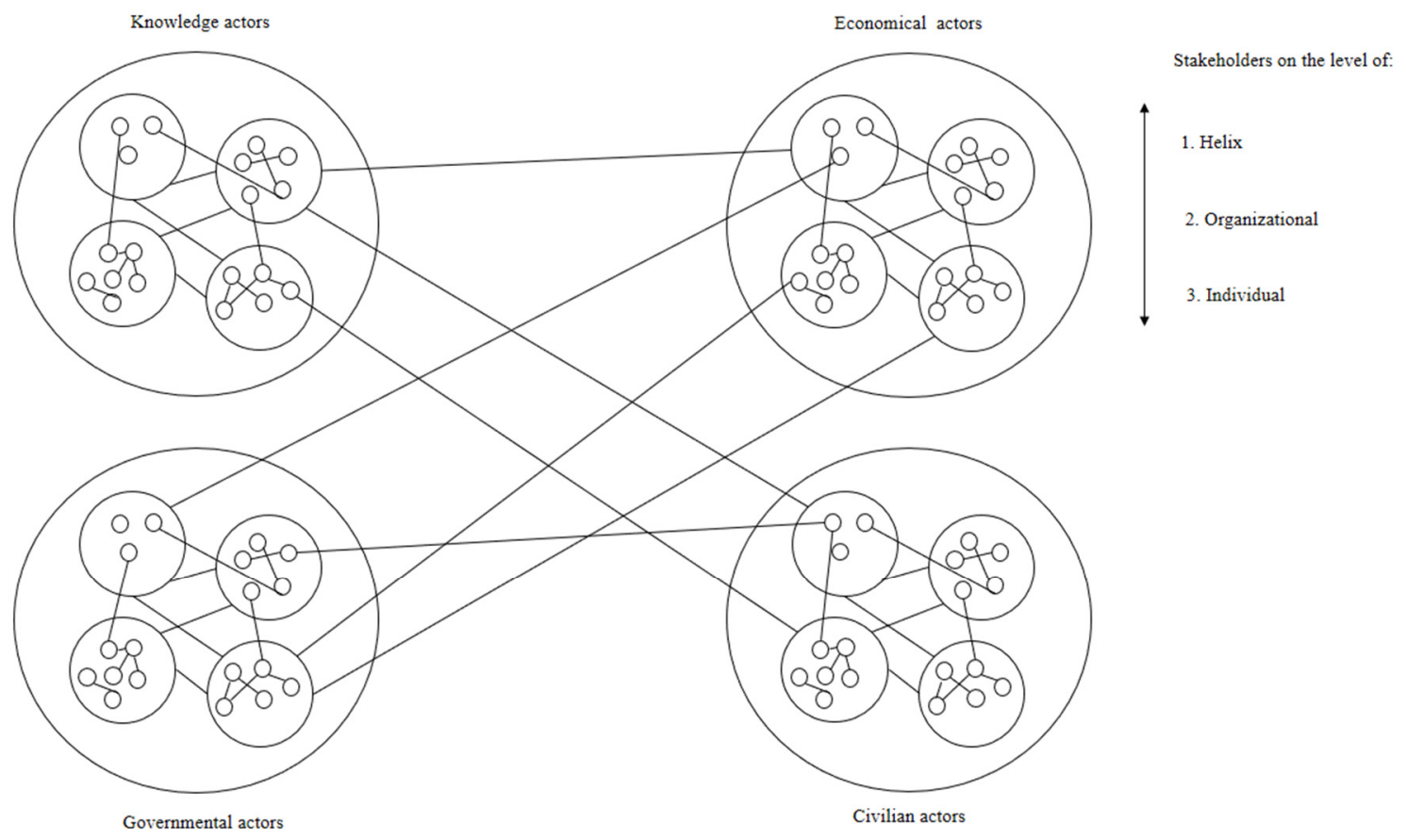

Figure 1. Conceptualization of the regional open innovation network. Stakeholders within the ecosystem exist on helical, organizational, and individual levels. The stakeholders in the network interact with one other on these three different levels. 


\subsection{Urban Living Lab as an Intervention for Urban Acupuncture}

Within the last twenty years, urban living labs (ULLs) have been widely studied as operationalizations used to share assets in such networks through the facilitation of sustainable collaborative product and service development processes [27]. An urban living lab can be conceptualized as a project-based and geographically defined process that facilitates an experimental window and structures distributed innovation processes [27]. Such constellations can be understood as having three layers [26]. The top layer is the ecosystem, where the aim is to exchange knowledge and stimulate collaboration. The middle layer contains the processes of co-creation, testing, and innovation development within delineated projects. The bottom layer consists of the research and development tools and methods that facilitate knowledge transfer. Hence, Schuurman [26] conceptualizes ULLs as interventions in the OI network, defined in space and time, that bridge the gap between a regional open innovation network and the stakeholders within it.

The aim of this study is to gain insights in how to attract, identify, and activate stakeholders within a regional innovation ecosystem. Because of its connecting nature, we envision an urban living lab as a small-scale intervention that facilitates the gathering and spillover of distributed knowledge within the regional OI-network. In accordance with the concept of urban acupuncture [44,45], we make the assumption that an ULL can help in attracting, identifying, and activating regional stakeholders. Here, the urban living lab intervention serves as a catalyst for local stakeholders to engage and participate in the processes of urban planning [45]. Because of this catalyst effect, barriers for local stakeholders to contribute their knowledge are lifted, resulting in a wider support base among stakeholders originating from the different helices [19].

\subsection{Stakeholder Roles in Urban Living Labs}

Different interpretations and applications of a ULL can be incongruent. Steen and van Bueren [27] showed that an ULL can have different characteristics depending on the conceptualization. One characteristic is the overarching aim to experiment in order to discover solutions for specific problems or problem domains (e.g., innovation in healthcare, innovation in climate-neutral investments, etc.). This implies that each problem domain in the same regional open innovation ecosystem requires different types of knowledge assets, which necessitates theme-specific stakeholders. This also implies that stakeholders should have dynamic roles during the ULL project. Juurjärvi and Pesso [31] found that stakeholder roles vary from being an informant to a tester, as well as a contributor and co-creator in the development process [46]. Moreover, city representatives are conceptualized as enablers who create the vision and allocate resources; firms and local service providers are seen as utilizers who produce place-based knowledge; educational institutions are considered providers of R\&D methods and systematic augmentation of knowledge; and civilians in the ULL are seen as users. However, these roles may differ based upon the specific ULL. This suggests the presence of dynamic multi-role actor relationships, which have not been thoroughly studied [46].

\subsection{Research Question and Research Design}

We see regional open innovation ecosystems as collections of stakeholders who possess different kinds of assets that are drivers of regional development. In order to discover solutions for complex societal problems, stakeholders with these assets need to be identified, attracted, and activated for innovation and/or service development.

Various frameworks have been supplied in the current literature in order to identify the nature of stakeholders' roles in such OI ecosystems [31], to provide insights regarding how to set up a constellation of OI projects, and in order to assess the outcomes of OI in innovation projects [18,35-37]. In addition, OI collaborations, alliance management research, and public-private partnerships (PPP) literature offer a variety of frameworks that provide guidelines for assessing stakeholders based on their potential contribution to an OI project [47]. For example, based on this literature, Sandulli and colleagues [47] 
identified three main aspects as important stakeholder attributes that contribute to the success of OI collaborations: (1) actor complementarity, (2) actor commitment, and (3) actor compatibility. Other literature regarding stakeholder analysis shows that there are various methods for identifying appropriate stakeholders, including using graphical mappings [48,49], using guidelines to determine the direction and dimensions (internal, external, and inter-firm network) in which to look for these stakeholders [49,50], and using selection criteria (functional, geographical, and knowledge/abilities) to identify the potential contribution of stakeholders $[49,51]$. While this literature provides insights into stakeholder assessment and identification on a general level, in this paper, we interpret OI ecosystems as unique and bound to the local urban context in terms of the actors present within the regional ecosystem and their assets [29,30]. In this context, little is known about how to attract, identify, and activate stakeholders for OI projects and what processes are most appropriate for these purposes.

In order to explore and gain insight into these attraction, identification, and activation processes, this study applies an intervention/project format based upon the literature presented above, which is intended to enable these processes. Here, an urban living lab can be utilized to operationalize stakeholders and their assets originating from the regional innovation ecosystem. By utilizing a ULL, we create three boundary conditions that contribute to the attraction, identification, and activation processes. First, a narrow topical focus is used to validate the relevance and contribution of joining stakeholders. In order to attract assets in the distributed, open-ended urban environment, actors should be drawn in by the issue, not through inter-organizational relationships [52]. Second, the ULL facilitates the development of an open-ended network to encourage stakeholders to join and leave the intervention/project. Here, pre-defined consortia do not fully capture the assets in the distributed open-ended urban environment [14]. Third, we generate an experimental environment $[53,54]$ within the ULL in which design-thinking methodology can be applied to bridge practical and communication barriers between participating stakeholders [55].

\section{Materials and Methods}

In order to study these processes of attraction, identification, and activation, we applied a participatory action research design [56,57], taking an interpretivist epistemological approach. In this approach, research, and phenomenon are closely intertwined, facilitating an in-depth, open-ended, and nuanced understanding. The methodology section of this paper is divided into three parts. First, we discuss the theoretical aspects of our action research intervention. Next, we describe the practical context of this intervention. Finally, we discuss the data collection and analysis strategies we applied.

\subsection{Intervention Design}

Building upon the theoretical insights we discussed earlier, an urban living lab intervention in the regional open innovation ecosystem was designed and applied. This intervention design was formulated on three different levels (in line with Schuurman [26]), which together constituted the inclusion criteria for our research design.

At the macro level, the quadruple helix innovation framework [19] was used to create an initial constellation of stakeholders involved in the intervention. As local knowledge actors, Ghent University and the imec research institute were involved both (funded) as brokers (coordinating the ecosystem interactions) and enablers (performing research activities and product development). As a local government actor, the municipality was involved as an enabler (providing funding and access to domain-specific communities) and as a utilizer (wanting to appropriate the intervention to stimulate sustainable urban innovation). Regarding civil society (users), a community of senior citizens, students, volunteers, and healthcare professionals was involved. However, as is discussed under boundary conditions in the next section, this was only an initial constellation that should provide momentum for the broader regional open innovation ecosystem. 
At the meso level (project), the intervention process was designed as an urban living lab [27]. This led to a set of activities (workshops, experiments, discussion groups, etc.) aimed at the iterative co-creation of sustainable urban innovations embedded in a (hyperlocal) real-world environment being developed and conducted over the course of one year (the micro-level activities). In order to gradually understand the central topic or challenge, and work toward a concrete ICT solution with all involved stakeholder, this study applied the process of design thinking [58,59]. We started with an 'emphasize phase' to understand the central challenge through interviewing and observing stakeholders. Next, we entered a 'co-creation' phase and co-shaped a conceptual solution for the central challenge. This concept then was materialized in the 'prototyping' phase to eventually test the prototype in a real life 'field trial'. This was all conducted in collaboration with the proper stakeholders representative with the quadruple helix innovation framework [19]. To study our research question, we formulated boundary conditions (conceptualized as stimuli) that potentially uncover the attraction and activation processes of urban stakeholders (Table 1).

Table 1. Boundary conditions of the intervention.

\begin{tabular}{cc}
\hline Boundary Condition & Grounding \\
\hline $\begin{array}{c}\text { Narrow focus (the issue) (immobile and lonely elderly } \\
\text { citizens) }\end{array}$ & $\begin{array}{c}\text { Create a specific topic in order to validate the relevance and contribution of } \\
\text { joining stakeholders based on this topic. To attract assets in the distributed } \\
\text { open-ended urban environment, actors are drawn in by the issue, not } \\
\text { through inter-organizational relationships [52]. }\end{array}$ \\
$\begin{array}{c}\text { Open-ended network } \\
\text { (driven by a core constellation) }\end{array}$ & $\begin{array}{c}\text { Create an open-ended network in order to encourage stakeholders, aside } \\
\text { from the core constellation, to join and leave the project. Pre-defined } \\
\text { consortia do not fully capture the assets in the distributed open-ended urban } \\
\text { environment [14]. No stakeholder inclusion or exclusion criteria are defined } \\
\text { to ensure an open-ended exploration of the phenomenon. }\end{array}$ \\
Temporal experimental & $\begin{array}{c}\text { Create an experimental environment, defined in space and time, where } \\
\text { stakeholders can share and contribute without obligation [35,36]. } \\
\text { Design-thinking methodology is applied in order to bridge practical and } \\
\text { communication barriers between the participating stakeholders [55]. }\end{array}$ \\
\hline environment with a design-thinking methodology &
\end{tabular}

\subsection{Context}

The intervention took place in the city of Ghent, Belgium, ran for 12 months in 2018, and focused on the topic of immobile and lonely elderly citizens (this topic was decided upon by the municipality). The project was set up as a collaboration between the City of Ghent (municipality), Ghent University (local university), and the R\&D company imec (regional technology center). In order to find a solution for the challenge of social isolation among elderly citizens, the project conducted an R\&D process that systematically involved a wide variety of civil stakeholders (e.g., senior citizens and volunteers), researchers (from the different knowledge institutes in the city), entrepreneurs, and local social caretakers originating from the Ghent neighborhood of 'Muide-Meulestede'. This neighborhood was chosen for the diversity of its inhabitants in terms of age and socio-economic status. In collaboration with the stakeholders, a senior-proof smart speaker was developed that detects social isolation by using a door sensor that measures the amount of visits an elderly citizen has and allows them to ask for social contact with a volunteer. The intervention involved 38 individuals from the different municipal departments, 21 individuals from four research institutes, 15 representatives from private organizations, 10 representatives from NGOs, and 33 citizens (senior citizens, students, and volunteers).

\subsection{Data Collection and Analysis}

Applying a participatory action research approach [38], the researchers took an active role in coordinating, executing, and participating in the project. The first role was that of project coordinator, which allowed the researchers to monitor the in- and out-flow of stakeholders of the project and safeguard the open-ended nature of the collaboration 
(macro level). The second role involved executing the different activities in the R\&D process (micro level). By participating so directly, the researchers gathered latent insights in a participatory observative manner. Moreover, these insights were gathered by analyzing different sources of evidence [60]. First, insights were gathered by observing phenomena and mechanisms which occurred during formal and informal meetings in the project, also known as soft data [60]. However, these were not structurally captured, as they were ethnographic observations and interpretations of the researchers who were active in the project. Secondly, different sources of hard data [60] were used as evidence as well, including e-mail communications, meeting reports from steering committees, initial project proposals, project reports, and project deliverables.

To develop a conceptual model, a series of inductive reflective exercises and conversations with involved stakeholders was conducted in order to structure, analyze, conclude on, and validate the main insights this paper provides (Table 2). These reflective exercises were executed by using a pluralistic approach that combined the perspectives of the authors in this paper. This process can be divided in three phases:

Table 2. Phases of structuring, analyzing, and concluding on the main research insights.

\begin{tabular}{cc}
\hline Phase & Method \\
\hline $\begin{array}{c}\text { Phase one: Collection, coding, and } \\
\text { first analysis of the observed } \\
\text { phenomena }\end{array}$ & $\begin{array}{c}\text { In order to collect and analyze the observed phenomena and hard data, the researchers } \\
\text { produced a longlist of phenomena they observed during the project. Within a workshop } \\
\text { format, first-order data [61] were written down on a whiteboard. Next, this longlist was } \\
\text { coded and structured in order to generate second-order data [61] and to find connections } \\
\text { between the applied boundary conditions and phenomena which occurred during the } \\
\text { project. As a result, a conceptual model was constructed, describing the relation between } \\
\text { the intervention, the boundary conditions, and the observed processes. }\end{array}$ \\
$\begin{array}{c}\text { Phase two: Validation of the } \\
\text { gathered insights }\end{array}$ & $\begin{array}{c}\text { In the second phase of the analysis, the conceptual model produced in phase one was } \\
\text { validated by the involved stakeholders. This was performed by having formal and informal } \\
\text { conversations and discussions with the civil servants and social caretakers who were } \\
\text { participating or involved in the project [60]. In this manner, the insights from phase one } \\
\text { were further polished and adjusted. }\end{array}$ \\
$\begin{array}{c}\text { Phase three: Answering the central } \\
\text { research question }\end{array}$ & $\begin{array}{c}\text { As a last analysis phase, the second-order insights were filtered according to their relevance } \\
\text { for tackling the central research question. This was performed by applying a workshop } \\
\text { format with all the involved authors of this paper. Relevant insights were identified and } \\
\text { processed in a final and purified conceptual model. }\end{array}$ \\
\hline
\end{tabular}

\section{Results}

\section{An Urban Acupuncture Framework (UAF)}

\section{Phase 1: Urban Acupuncture as a Conceptual Model}

The first phase (outlining the identification and attraction processes) converged with the formulation of an 'urban acupuncture framework' (Figure 2). By establishing an experimental window inside the ecosystem, the intervention acted as a centripetal force for actors from all four helices distributed throughout the urban tissue. We conceptualized and appointed this mechanism in relation to the concept of urban acupuncture originally coined by Manuel de Solà-Morales Rubio [44] in an urban planning context. The experimental nature of the intervention, combined with the hyperlocal materialization (a hacked smart speaker), made it highly visible, and it was further amplified through (re)mediation and (re)presentation of the artefact (smart speaker) through networks of networks and traditional media broadcasts (as a result of the high storytelling value and the 'demo-effect'). This was evidenced by the project being covered over 20 times on regional broadcast media, printed press, and public presentations (considered disproportionate compared to other collaborations by all involved stakeholders even though almost no budget or effort was allocated to professional communication). Hence, this constituted a radical translation from strategy to artefact, which served as a broadcasting beacon for collaboration. As such, the intervention served as an 'acupuncture needle' within the regional ecosystem 
(tissue), pulling the nerves of the ecosystem in order to identify and attract the relevant stakeholders, extending beyond the artefact itself (ripple-in and ripple-out processes) [45].

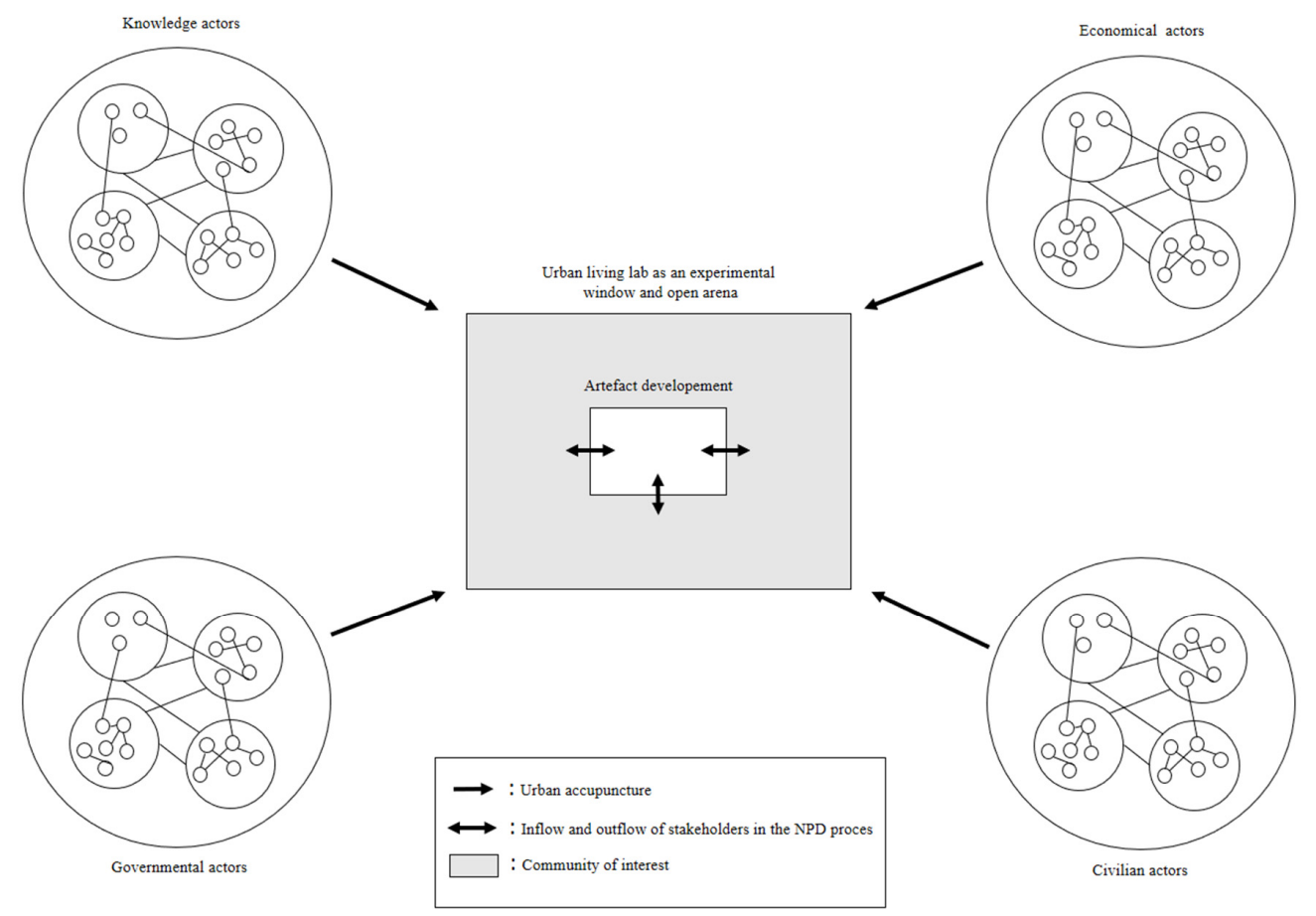

Figure 2. Visual representation of the urban acupuncture framework (UAF).

Phase 2A: Stakeholder Identification Processes

The intervention attracted and formalized both interest and engagement at the individual level as well as at the organizational level. However, organizational network ties, in all cases, originated from the interest and initiative of an individual actor within the organization. For example, a local higher education institute (Arteveldehogeschool) became involved in the project, with students volunteering to visit elderly citizens and co-create the senior-proof smart speaker (see Figures 3 and 4). However, this organizational-level connection was activated through the ad hoc interest of an individual teacher working at the institute. The teacher could be considered a latent tie of the core consortium, which was identified and activated through the experimental nature of the intervention. The hands-on and materialized nature of the urban experiment (disseminated through news media) triggered the contact and the transformation of the latent tie to a strong tie in the collaboration. The open-ended and time-boxed nature enabled formal involvement at the organizational level, hence allowing the activation of the assets of this urban actor.

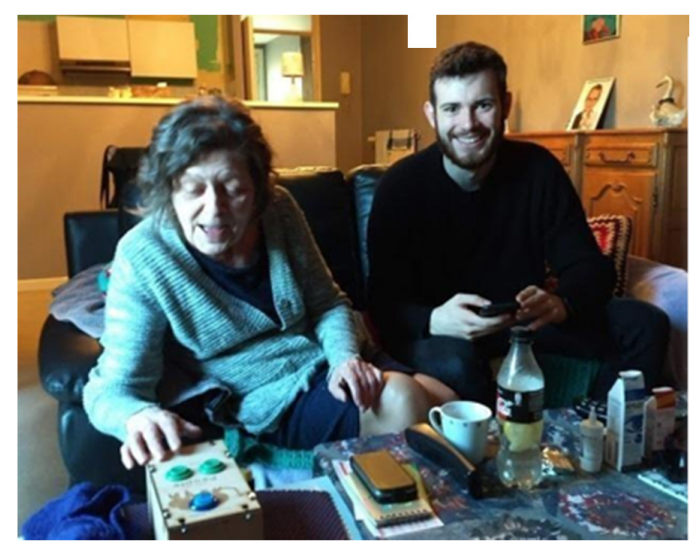

Figure 3. An elderly citizen tests the senior-proof smart speaker with a student volunteer. 


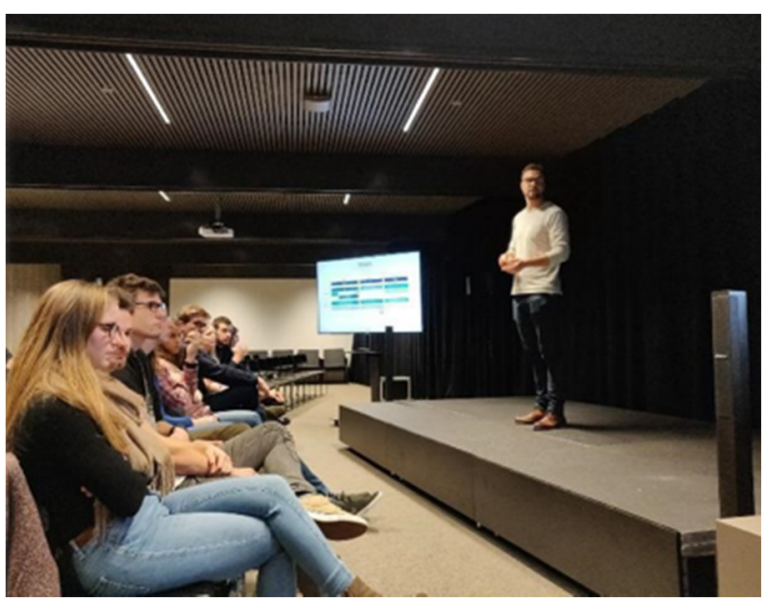

Figure 4. A researcher from Ghent University gives a lecture on the project outcomes.

However, although the central artefact was the main draw, not every attracted stakeholder (ripple in) stayed (equally) involved over time (ripple out). For example, three city council departments stepped back when the developments went in a direction that no longer provided value for them; most of the academics involved contributed, became interconnected, and went their own separate ways (which can be described as collaborative spillovers); and the involvement of the higher education institution was limited to a single semester. Such dynamic inflow and outflow of stakeholders requires stakeholder identification and selection to be conceptualized on a continual basis. This entails a more dynamic understanding of collaboration ecosystems as actors come and go over time and an understanding that ecosystem collaborations should not be considered fixed but should rather be studied from the perspective of the ecosystem lifecycle.

Moreover, these processes can be categorized as a combination of active (active outreaching through first-order network ties), secondary active (identification and activation through second-order network ties), and passive modes (non-controlled content remediation addressing latent or non-existing connections) of attraction. These modes evolved over time (Table 3 and Figure 5). The project was formed with the core constellation of stakeholders. Next, according to the stage the project was in, different stakeholders joined or showed interest in the project by attracting in these modes (Table 3. Moreover, in the early stages of the intervention/project (the initiation phase), (pro)active identification and communication toward actors in the regional innovation system were required. This implied scanning the environment (activating existing networks) for valuable urban actors and actively approaching these stakeholders. These stakeholders then co-shaped the collaborative network through autonomous, non-solicited communication practices within organizational bodies, (professional) issue networks, and personal weak and strong connections. For example, a local social caretaker was approached through the organizational actor (City of Ghent) and was immediately convinced of the value of the project at a personal level. She then helped find elderly citizens to enroll in the research steps in order to obtain their feedback. These actors could not have been identified, contacted, and activated without the remediated experiment-oriented communication practices that took place within the network of this local social caretaker. Here, the pro-active stakeholder identification transformed into a hybrid form of active and passive stakeholder identification and attraction. Accordingly, by pro-actively activating the first-order network of the project, second-order network ties could be activated as well. 
Table 3. Phases of the project and the nature of the identification and attraction processes. In each phase the number of interested stakeholders and how the intervention/project attracted them is illustrated. A more detailed version of this table can be found in Appendix A.

\begin{tabular}{|c|c|c|c|}
\hline Phase during the Project & $\begin{array}{l}\text { Active Stakeholder } \\
\text { Identification and } \\
\text { Attraction } \\
\text { (First-Order Networks) }\end{array}$ & $\begin{array}{c}\text { Secondary Active } \\
\text { Stakeholder Identification } \\
\text { and Attraction } \\
\text { (Second-Order Networks) }\end{array}$ & $\begin{array}{l}\text { Passive Stakeholder } \\
\text { Identification and } \\
\text { Attraction }\end{array}$ \\
\hline $\begin{array}{c}\text { Phase: Project acquisition and setting } \\
\text { up the core } \\
\text { constellation }\end{array}$ & $N=4$ & & \\
\hline $\begin{array}{l}\text { Phase: Initiation phase: start of the } \\
\text { intervention/project }\end{array}$ & $N=15$ & & \\
\hline Phase: Materialization of the project & & $N=12$ & $N=1$ \\
\hline $\begin{array}{l}\text { Phase: Field trial of the } \\
\text { project (proof of concept) }\end{array}$ & & $N=12$ & \\
\hline Phase: End of the project field trial & & $N=1$ & $N=3$ \\
\hline $\begin{array}{l}\text { Phase: post media coverage and } \\
\text { networking events }\end{array}$ & & $N=17$ & $N=13$ \\
\hline
\end{tabular}

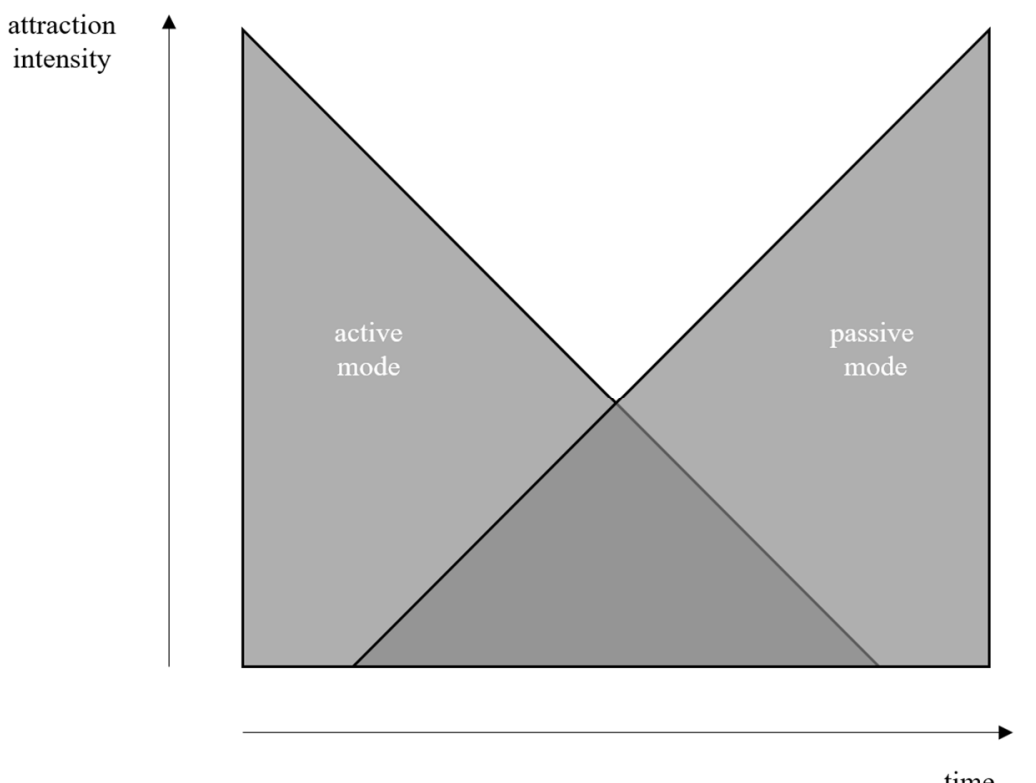

Figure 5. Conceptual representation of active and passive attraction processes over time.

Consequently, as the intervention progressed and gained momentum, the active mode or communication was gradually replaced by the passive mode. As the experimental window and the research activities proceeded, insights and stories were generated and the project started to materialize (it became more tangible for outsiders), the acupuncture effect of the project grew even stronger. This materialization allowed all the actors involved to disseminate information about the project and to network at events, etc. In addition, the nature of the experiment created stories that media actors value, which stimulated traditional mass media communication and created new cycles of communication and distribution. For example, following a field trial with a prototype of the senior-proof smart speaker, newspapers, radio shows, and a local television station covered the project and featured several of the actors involved (researchers, politicians, civic servants, senior citizens, students, etc.). This attracted actors who were not identified by (and were unknown to) the actors within the ecosystem and who originated from all helices (also outside the 
defined geographical boundaries) and expressed an interest in exploring the possibility of collaborating in the network. Because of the different natures (distribution partners, production partners, network actors, local research groups, and similar projects) of these new stakeholders, more representative collaborations according to the quadruple innovation framework could be established. However, despite the number of stakeholders who became interested (Table 3, phase: post media coverage and networking events, $\mathrm{N}=30$ ) in the project, the project still experienced difficulties in collaborating with interested private partners. These potential partners were reticent toward the adoption of the smart speaker within their own business processes. After exploratory conversations with these private partners, a "not invented here syndrome" [62] was observed by the researchers. Because of the late involvement of these private partners within the NPD process, the motivation to structurally collaborate was a tough barrier to overcome.

Last to mention, and as a result of the network ties which were generated, the project was pitched at a smart-city competition organized by the Flemish government called "De Slim-in-de-stad prijs". The project won this competition, which then resulted in funding for a new cycle of development for the senior-proof smart speaker. Hence, the process of urban acupuncture can be considered a mechanism to identify distributed knowledge in the (local) environment.

\section{Phase 2B: A Dynamic and Layered Approach to Stakeholder Involvement}

Actor identification does not (necessarily) imply activation and selection. When conceptualizing innovation ecosystems as dynamic entities, the capability to appropriate the assets of the identified urban stakeholders could be considered the absorptive capacity [63] of the ecosystem. This represents the capacity of the ecosystem to actively manage and absorb the potential value of new ecosystem actors.

The open-ended boundary condition required the construction of a permeable 'outer layer' of stakeholders designed to absorb incoming connections (Figure 6). This can be considered an 'issue-based network' (related to the narrow-focus boundary condition). Such an outer layer captured and formalized initial interest. At this level, the dissemination of the project outcomes took place through electronic newsletters that informed and invited deeper engagement. Even at this lower level of involvement, several connections were established between superficially connected urban actors (only loosely related to the materialized artefact at the core of the project). From this layer, new collaborations and projects emerged, such as a collaboration between academics working on a project on intergenerational storytelling and local civil servants working on senior healthcare. Throughout the urban living lab project, several urban actors were involved more directly in shaping and testing the artefact. However, depending on the phase of development and based on shifts in orientation, the interest and relevance of certain stakeholders varied over time. Therefore, when a stakeholder showed interest, the intervention allowed dynamic shifts in involvement and commitment. Similar to the attraction processes, this entailed both an active mode (seeking resources) and a passive mode (actor initiative). Given this, the outer layer also acts as an organizational layer to preserve social capital.

These dynamic engagements can be conceptualized as forming a layered onionlike organizational structure (Figure 6) with flexible memberships in the various layers, allowing for different levels of involvement and formalized communication practices (enabling for inflow and outflow). Stakeholder involvement can be categorized according to three prototypical layers. The outer layer consists of a loose and permeable issue-based network. In this layer, stakeholders may not even be aware of the project, but stakeholders in this layer may offer high levels of preserved collaborative potential (both outside-in and inside-out). In the middle layer, stakeholders are aware and more actively involved in the project but are not actively participating in the development processes. Once these stakeholders can (temporarily) contribute, they can be activated within the project itself. This flexible approach was considered to be efficient by the partners involved because it could adapt to changes in scope and resources and subsequent needs for different assets, etc. Hence, such a model contributes to the absorptive capacity of the innovation 
ecosystem. However, funding and strategic partnerships were required to ensure minimal commitments of participating stakeholders. Individuals who were excluded from funding or strategic partnerships could not easily maintain sustained commitments at deep levels in this layered engagement model. Finally, this dynamic and layered approach to stakeholder involvement also illustrates the ripple-in and ripple-out effects of urban acupuncture.

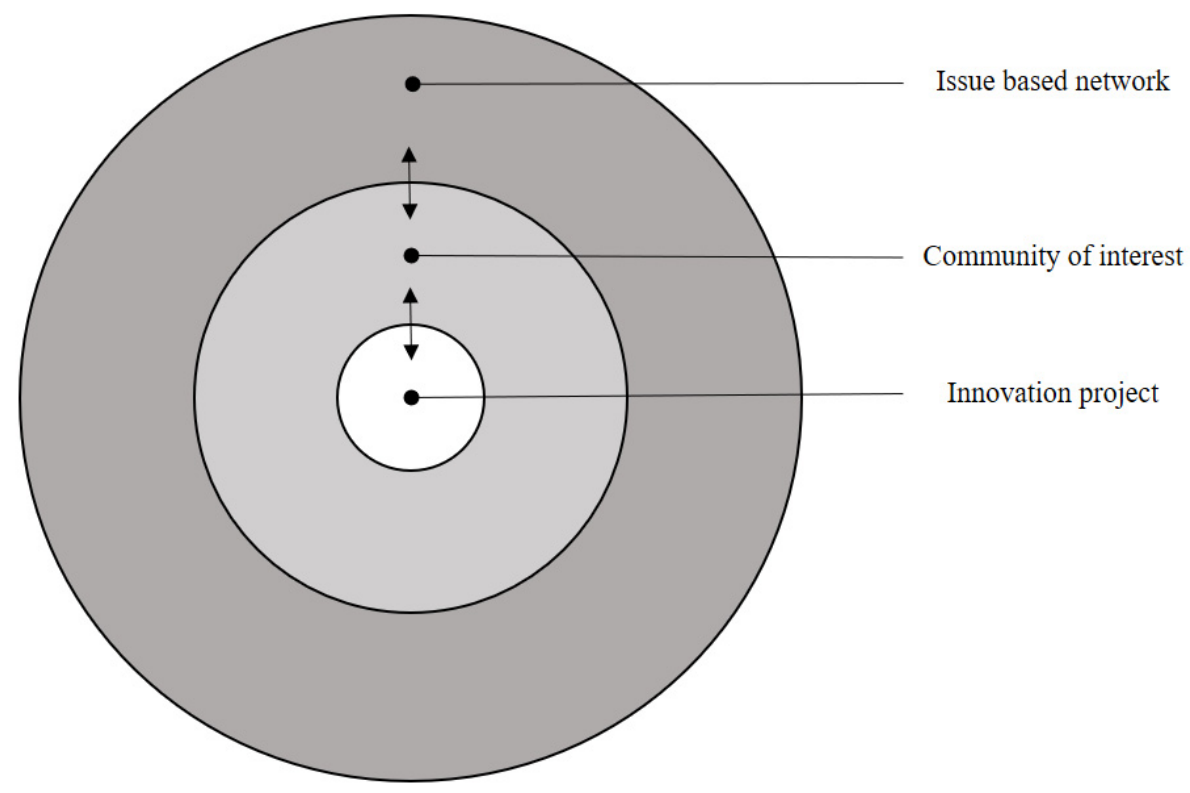

Figure 6. A dynamic and layered approach to stakeholder involvement.

\section{Discussion}

Open innovation ecosystems are increasingly becoming the preferred strategy for tackling complex societal problems. Such problems often arise in urban areas, which increasingly position cities as drivers for sustainable change. Hence, regional social open innovation ecosystems [15] are being promoted to support sustainable urban development and to tackle 'wicked societal problems'. We conceptualized the regional open innovation ecosystem as containing fractal, multi-level, multi-modal, and multi-lateral configurations of dynamic tangible and intangible assets within a narrow geographically bound environment [19,22] and as a network of networks [42]. The appropriation of distributed knowledge [20] requires social interactions that establish ties and activate resources or assets, especially tacit knowledge assets, among urban stakeholders. However, such interactions and processes in the regional open innovation ecosystem, specified in this unique and stakeholder-specific regional context, remain under-explored.

Current literature offers a variety of generic frameworks that provide overviews of different forms of OI $[7,25]$ and insights in what roles stakeholders take in OI projects [31], how to set up a core constellation for OI projects [46], how to operationalize OI projects by applying an urban living lab [27], and how to assess these stakeholders according to their match with the OI project. While the premise of such ecosystems entails the successful appropriation of distributed assets in the urban environment, little is known about identification, attraction, and selection mechanisms for such assets. More specifically, the processes on how to attract, identify, and activate context-specific stakeholders has not been reported before in existing literature. This paper aimed to fill this gap within the specific context of a regional OI ecosystem by means of an explorative, participatory research trajectory.

To study these processes, we applied an urban living lab process and rapid materialization, which made the distributed knowledge more tacit [21], in an intervention within a regional ecosystem with three boundary conditions to attract and activate relevant stakeholders: a specific and narrow topical focus, an open-ended network, and a local 
temporal experimental environment. These boundary conditions had a clear impact on the identification, attraction, and activation of stakeholders within the regional innovation network. More specifically, gravitating toward a specific and narrow topical focus aided in identifying prime collaborators in the regional ecosystem. Installing an open-ended network with open knowledge sharing and wider communication attracted new partners from the ecosystem. Finally, setting up an experimental environment bound by time and place facilitated the process of activating the partners in this regional network to work together for a common goal. This experimental window was set up by applying a design-thinking methodology $[58,59]$ in order to collaborate with all proper stakeholders according to the quadruple helix innovation framework [19]. Moreover, by setting up the urban living lab project by applying the urban acupuncture framework, the outcomes were regarded as successful by the initiators. By attracting and activating various stakeholders from the local ecosystem, the project resulted in a concrete solution (the senior-proof smart speaker) that was able to satisfy the needs of the different involved stakeholders and was supported by a diversity of insights and contributions from these local stakeholders.

Nevertheless, even though this intervention resonated within the regional ecosystem and was able to attract new stakeholders, activating interested private stakeholders proved to be more difficult than anticipated. Namely, following the research phase of our project, private stakeholders showed interest yet remained reticent to adopt the smart speaker concept in their own business processes. Here, based upon our observations and analysis, we assume that these private stakeholders displayed the so-called 'not-invented-here syndrome' [62], suggesting that they were not involved early enough in the NPD processes to take up ownership afterwards. In addition, current literature, from an economical perspective, regarding the macro-dynamics of open innovation suggests that the dynamic balance between closed OI, market OI, and social OI is required to reach high quantitative and qualitative economy growth and more sustainable innovations, which can serve as a driver for countering the growth limits of capitalism [7,25,64]. In our case study, which focused on the micro-dynamics of social OI in the context of a quadruple helix regional innovation project, we found that an imbalance occurred in terms of the fourth helix (economical actors). This was caused by the fact that these private actors were involved only at a later stage of the project, resulting in an absence of critical 'go-to-market' information which put a hold on the effective implementation of the resulting innovation. Therefore, we recommend involving private partners (needed for production, distribution, and roll-out) as soon as possible in similar projects in order to prevent the 'not-invented-here' syndrome. Ideally, these private partners are represented within the core constellation.

From a methodological perspective, the insights are the result of an interpretation of participatory action research. Since such an approach does not aim to generalize findings and produce a unified understanding or a single answer to the research question, the analysis conducted by the authors is one of many possible truths. Still, these results contribute to the pluralistic understanding of identification, selection, and activation processes in regional open innovation ecosystems. Therefore, a critical comparison with different regional ecosystem interventions (and variations of these boundary conditions) is required. Further research is necessary to determine the impact of alternative boundary conditions on the dynamics within regional open innovation ecosystems. Nevertheless, the conceptual representations in this paper offer a framework to analyze such phenomena in other contexts and/or with different boundary conditions.

Furthermore, since this research is explorative and interpretive in nature, and thus the context and phenomenon are strongly intertwined, it would be useful to consider these insights in other urban living lab projects in different contexts (both a priori and in retrospect). Regarding the dynamic capabilities and the increased connective capacity of the regional open innovation ecosystem, this could be further investigated at the level of network ties and network analysis. This would allow for a better understanding of evolving social capital and network structures within a regional innovation ecosystem and 
their relation to urban acupuncture strategies (e.g., through the application of longitudinal social network analysis).

\section{Conclusions}

The aim of this study was to address the gap in current literature regarding the exploration and influencing of dynamic ecosystem processes of identification (finding), attraction, and activation of collaborative actors in sustainable regional OI ecosystems. By examining the case study of the "City of People: challenges in healthcare" project within the City of Ghent, we gathered explorative insights in this matter. This was executed by conducting a participatory action research approach within this project. Firstly, we analyzed the identification, attraction, and activation processes for stakeholders in an open innovation project within a regional innovation ecosystem in a thorough and detailed manner. Secondly, we applied the urban acupuncture framework (UAF) that structures such processes according to the concept of urban acupuncture $[44,45]$. Thirdly, we formulated specific recommendations in order to improve these processes based on this analysis and the developed framework.

Consequently, based on this study, we recommend that local policymakers manage similar open innovation projects in a phased and chronological manner. Following the mechanics of the UAF, urban living lab projects should begin with active stakeholder identification, using the frameworks for stakeholder analysis and assessment provided in the current literature. When the project materializes and becomes more tangible, stakeholders who possess assets that are a good fit for the specific project gradually are attracted to it and therefore are more easily identified due to the issue-based nature of the project. At this point, the active identification mode shifts to a more passive mode of stakeholder identification. Finally, this study also explored the application of a "community of interest," which showed that necessary and useful assets can be attracted and activated when the right momentum is achieved within the project.

Author Contributions: Conceptualization, B.R. and B.B.; methodology, B.R, B.B. and W.D.; validation, B.R. and B.B.; formal analysis, B.R. and B.B.; investigation, B.R. and B.B.; resources, B.B. and D.S.; data curation, B.R., B.B. and W.D.; writing-original draft preparation, B.R.; writing-review and editing, B.B., W.D. and D.S.; visualization, B.R.; supervision, B.B.; project administration, B.B. and D.S.; funding acquisition, B.B. and D.S. All authors have read and agreed to the published version of the manuscript.

Funding: This research was funded by the City of Ghent.

Institutional Review Board Statement: Not applicable.

Informed Consent Statement: Not applicable.

Data Availability Statement: Not applicable.

Conflicts of Interest: The authors declare no conflict of interest.

\section{Appendix A}

Table A1. Phases of stakeholder attraction and the nature of the identification and attraction processes.

\begin{tabular}{cccc}
\hline Stakeholder & $\begin{array}{c}\text { Active Stakeholder } \\
\text { Identification and } \\
\text { Attraction } \\
\text { (First-Order Networks) }\end{array}$ & $\begin{array}{c}\text { Secondary Active } \\
\text { Stakeholder Identification } \\
\text { and Attraction } \\
\text { (Second-Order Networks) }\end{array}$ & $\begin{array}{c}\text { Passive Stakeholder } \\
\text { Identification and } \\
\text { Attraction }\end{array}$ \\
\hline $\begin{array}{c}\text { imec } \\
\text { Technology \& methodological } \\
\text { partner } \\
\text { Helix: Private actor } \\
\text { Organizational level }\end{array}$ & $X$ \\
\hline
\end{tabular}


Table A1. Cont.

\begin{tabular}{|c|c|c|c|}
\hline Stakeholder & $\begin{array}{c}\text { Active Stakeholder } \\
\text { Identification and } \\
\text { Attraction } \\
\text { (First-Order Networks) }\end{array}$ & $\begin{array}{c}\text { Secondary Active } \\
\text { Stakeholder Identification } \\
\text { and Attraction } \\
\text { (Second-Order Networks) }\end{array}$ & $\begin{array}{c}\text { Passive Stakeholder } \\
\text { Identification and } \\
\text { Attraction }\end{array}$ \\
\hline \multicolumn{4}{|c|}{ Project Acquisition (before the start of the project) } \\
\hline $\begin{array}{c}\text { Ghent University } \\
\text { Methodological partner } \\
\text { Helix: Knowledge actor } \\
\text { Organizational level }\end{array}$ & $X$ & & \\
\hline $\begin{array}{c}\text { City of Ghent } \\
\text { Executive partner } \\
\text { Helix: Governmental actor } \\
\text { Organizational level }\end{array}$ & $X$ & & \\
\hline $\begin{array}{c}\text { OCMW Gent } \\
\text { Executive partner } \\
\text { Helix: Governmental actor } \\
\text { Organizational level }\end{array}$ & $X$ & & \\
\hline \multicolumn{4}{|c|}{ Initiation phase: start project in the neighborhood (ULL) } \\
\hline $\begin{array}{l}\text { Neighborhood social workers } \\
\qquad(\mathrm{N}=3) \\
\text { Co Creation partner } \\
\text { Helix: Governmental partner } \\
\text { Individual level }\end{array}$ & $X$ & & \\
\hline $\begin{array}{l}\text { Neighborhood elderly citizens } \\
\qquad(\mathrm{N}=12) \\
\text { Co Creation partner } \\
\text { Helix: Civilian actors } \\
\text { Individual level }\end{array}$ & $X$ & $X$ & \\
\hline \multicolumn{4}{|c|}{ Materialization of the project } \\
\hline $\begin{array}{l}\text { Lecturer of Artevelde } \\
\text { Hogeschool } \\
\text { Co Creation partner } \\
\text { Helix: knowledge actor } \\
\text { Individual level }\end{array}$ & & & $X$ \\
\hline $\begin{array}{l}\text { Students "social work" of } \\
\text { Artevelde Hogeschool } \\
(\mathrm{N}=12) \\
\text { Co Creation \& testing partner } \\
\text { Helix: Knowledge actor } \\
\text { Organizational level }\end{array}$ & & $X$ & \\
\hline
\end{tabular}

Field trial of the project (proof of concept)

Neighborhood elderly citizens
Participants for the project
field-test $(\mathrm{N}=12)$
Helix: Civilian actors
Individual level

Regional television

broadcasting station

Made a television report of the project

Helix: Private actor

Organizational level 
Table A1. Cont.

\begin{tabular}{|c|c|c|c|}
\hline Stakeholder & $\begin{array}{c}\text { Active Stakeholder } \\
\text { Identification and } \\
\text { Attraction } \\
\text { (First-Order Networks) }\end{array}$ & $\begin{array}{c}\text { Secondary Active } \\
\text { Stakeholder Identification } \\
\text { and Attraction } \\
\text { (Second-Order Networks) }\end{array}$ & $\begin{array}{l}\text { Passive Stakeholder } \\
\text { Identification and } \\
\text { Attraction }\end{array}$ \\
\hline \multicolumn{4}{|c|}{ End of the project field-trial } \\
\hline $\begin{array}{l}\text { Regional radio broadcasting } \\
\text { station } \\
\text { Made a radio report of the } \\
\text { project } \\
\text { Helix: Private actor }\end{array}$ & & & $X$ \\
\hline $\begin{array}{l}\text { (Regional) newspaper }(\mathrm{N}=2) \\
\text { Distributed an article } \\
\text { regarding the project } \\
\text { Helix: private actors }\end{array}$ & & & $X$ \\
\hline \multicolumn{4}{|c|}{ Post media coverage and networking events } \\
\hline $\begin{array}{l}\text { Distribution partners }(\mathrm{N}=15) \\
\text { Partners who could possibly } \\
\text { help in the further distribution } \\
\text { of the projects' product. } \\
\text { Helix: Private actors }\end{array}$ & & $X$ & $X$ \\
\hline $\begin{array}{l}\text { Production partners }(\mathrm{N}=5) \\
\text { Partners who could help in } \\
\text { the production process of } \\
\text { projects' product when } \\
\text { implemented in the market. } \\
\text { Helix: Private actors }\end{array}$ & & $X$ & $X$ \\
\hline $\begin{array}{c}\text { Network actors }(\mathrm{N}=2) \\
\text { Partners who gave access to a } \\
\text { new network of potential } \\
\text { partners. } \\
\text { Helix: Private actors }\end{array}$ & & $X$ & $X$ \\
\hline $\begin{array}{l}\text { Local research groups and } \\
\text { ventures for generating } \\
\text { knowledge spillover }(\mathrm{N}=2) \\
\text { Partners who could help in } \\
\text { the further development of } \\
\text { the projects' product. } \\
\text { Helix: Private and knowledge } \\
\text { actors }\end{array}$ & & $X$ & $X$ \\
\hline $\begin{array}{l}\text { Similar projects }(\mathrm{N}=3) \\
\text { Similar projects who aim to } \\
\text { tackle a similar "wicked" } \\
\text { problem as the project. } \\
\text { Helix: Private actors }\end{array}$ & & $X$ & $X$ \\
\hline $\begin{array}{l}\text { Potential partners for } \\
\text { collaboration in follow-up } \\
\text { projects or "project-forks" } \\
(\mathrm{N}=3) \text {. } \\
\text { Helix: Private and } \\
\text { governmental actors }\end{array}$ & & $X$ & $X$ \\
\hline
\end{tabular}




\section{References}

1. Chesbrough, H.W. Open Innovation: The New Imperative for Creating and Profiting from Technology; Harvard Business Press: Boston, MA, USA, 2003.

2. Laursen, K.; Salter, A. Open for innovation: The role of openness in explaining innovation performance among U.K. Manufacturing firms. Strateg. Manag. J. 2006, 27, 121-150. [CrossRef]

3. Chiang, Y.-H.; Hung, K.-P. Exploring open search strategies and perceived innovation performance from the perspective of inter-organizational knowledge flows. RED Manag. 2010, 40, 292-299.

4. Zeng, S.X.; Xie, X.M.; Tam, C.M. Relationship between cooperation networks and innovation performance of smes. Technovation 2010, 30, 181-194. [CrossRef]

5. Pateli, A.; Spyros, L. How functional involvement affects the transformation of external knowledge into innovation outcomes RED Manag. 2019, 49, 224-238.

6. Yun, J.J.; Park, K.; Im, C.; Shin, C.; Zhao, X. Dynamics of social enterprises-Shift from social innovation to open innovation. Sci. Technol. Soc. 2017, 22, 425-439. [CrossRef]

7. Yun, J.J.; Liu, Z. Micro-and macro-dynamics of open innovation with a quadruple-helix model. Sustainability 2019, 11, 3301. [CrossRef]

8. Yun, J.J.; Egbetoku, A.A.; Zhao, X. How does a social open innovation succeed? Learning from burro battery and grassroots innovation festival of india. Sci. Technol. Soc. 2019, 24, 122-143. [CrossRef]

9. Gassmann, O.; Enkel, E. Towards a theory of open innovation: Three core process archetypes. In Proceedings of the R\&D Management Conference (RADMA), Lisbon, Portugal, 7-9 July 2004.

10. Ahn, J.M.; Roijakkers, N.; Fini, R.; Mortara, L. Leveraging open innovation to improve society: Past achievements and future trajectories. RED Manag. 2019, 49, 267-278.

11. Chesbrough, H. Open Innovation: Researching a New Paradigm; Oxford University Press: Oxford, UK, 2006.

12. Grimm, N.B.; Faeth, S.H.; Golubiewski, N.E.; Redman, C.L.; Wu, J.; Bai, X.; Briggs, J.M. Global change and the ecology of cities. Science 2008, 219, 756-760. [CrossRef]

13. Hevner, A.; Chatterjee, S. Design science research in information systems. Des. Res. Inf. Syst. 2010, $22,9-22$.

14. Baccarne, B.; Mechant, P.; Schuurman, D. Empowered Cities? An Analysis of the Structure and Generated Value of the Smart City Ghent. In Smart City; Springer International Publishing: Cham, Switzerland, 2014.

15. Chesbrough, H.; Di Minin, A. Open social innovation. New Front. Open Innov. 2014, 16, 301-315.

16. Santoro, G.; Ferraris, A.; Vrontis, D. Open social innovation: Towards a refined definition looking to actors and processes. Sinergie Ital. J. Manag. 2018, 36. [CrossRef]

17. Cooke, P. The virtues of variety in regional innovation systems and entrepreneurial ecosystems. J. Open Innov. Technol. Mark. Complex. 2016, 2, 13. [CrossRef]

18. Chen, J.; Han, L.; Qu, G. Citizen innovation: Exploring the responsibility governance and cooperative mode of a "post-schumpeter" paradigm. J. Open Innov. Technol. Mark. Complex. 2020, 6, 172. [CrossRef]

19. Carayannis, E.G.; Grigoroudis, E.; Campbell, D.D.M.; Stamati, D. The ecosystem as helix: An exploratory theory-building study of regional co-opetitive entrepreneurial ecosystems as quadruple/quintuple helix innovation models. RED Manag. 2017, 48, 148-162.

20. Lakhani, K.R.; Panetta, J.A. The principles of distributed innovation. Innov. Technol. Gov. Glob. 2007, 2, 97-112. [CrossRef]

21. Yun, J.J.; Zhao, X.; Yigitcanlar, T.; Lee, D.; Ahn, H. Architectural design and open innovation symbiosis: Insights from research campuses, manufacturing systems, and innovation districts. Sustainability 2018, 10, 4495. [CrossRef]

22. Lönnqvist, A.; Käpylä, J.; Salonius, H.; Yigitcanlar, T. Knowledge that matters: Identifying regional knowledge assets of the tampere region. Eur. Plan. Stud. 2013, 22, 2011-2029. [CrossRef]

23. Moore, M.L.; Westley, F. Surmountable chasms: Networks and social innovation for resilient systems. Ecol. Soc. 2011, 16. [CrossRef]

24. Del Giudice, M.; Maggioni, V. Managerial practices and operative directions of knowledge management within inter-firm networks: A global view. J. Knowl. Manag. 2014, 18, 841-846. [CrossRef]

25. Yun, J.J.; Won, D.; Park, K. Entrepreneurial cyclical dynamics of open innovation. J. Evol. Econ. 2018, 28, 1151-1174. [CrossRef]

26. Schuurman, D. Bridging the Gap between Open and User Innovation? Exploring the Value of Living Labs as a Means to Structure User Contribution and Manage Distributed Innovation; Ghent University: Ghent, Belgium, 2015.

27. Steen, K.; Van Bueren, E. The defining characteristics of urban living labs. TIM Rev. 2017, 7, 21-31. [CrossRef]

28. Baldwin, C.; Von Hippel, E. Modeling a paradigm shift: From producer innovation to user and open collaborative innovation. Organ. Sci. 2010, 22, 1399-1417. [CrossRef]

29. Healey, P. Collaborative Planning: Shaping Places in Fragmented Societies; Macmillan International Higher Education: London, UK, 1997.

30. Carvalho, L. Smart cities from scratch? A socio-technical perspective. Camb. J. Reg. Econ. Soc. 2015, 8, 43-60. [CrossRef]

31. Juurjärvi, S.; Pesso, K. Actor roles in an urban living lab: What can we learn from suurpelto, finland? TIM Rev. 2013, 3, 22-27. [CrossRef]

32. Leminen, S.; Westerlund, M.; Nyström, A.-G. Living labs as open-innovation networks. TIM Rev. 2012, 2, 6-11. [CrossRef]

33. Huang, X.; Ma, L.; Li, R.; Liu, Z. Determinants of innovation ecosystem in underdeveloped areas—take nanning high-tech zone in western china as an example. J. Open Innov. Technol. Mark. Complex. 2020, 6, 135. [CrossRef]

34. Pascu, C.; Gómez-Barroso, J.L.; van Lieshout, M. User-led, citizen innovation at the interface of services. Info 2009, 11, 82-96. [CrossRef]

35. Leydesdorff, L.; Ivanova, I. “Open innovation" and "triple helix" models of innovation: Can synergy in innovation systems be measured? J. Open Innov. Technol. Mark. Complex. 2016, 2, 11. [CrossRef] 
36. Leydesdorff, L. Synergy in knowledge-based innovation systems at national and regional levels: The triple-helix model and the fourth industrial revolution. J. Open Innov. Technol. Mark. Complex. 2018, 4, 16. [CrossRef]

37. Yun, J.J.; Won, D.; Park, K. Dynamics from open innovation to evolutionary change. J. Open Innov. Technol. Mark. Complex. 2016, 2. [CrossRef]

38. Stuck, J.; Broekel, T.; Revilla Diez, J. Network structures in regional innovation systems. Eur. Plan. Stud. 2015, 24, 423442. [CrossRef]

39. Park, J.H. Brokerage activities in regional innovation networks: The case ofdaegu technoparkin korea. Int. J. Urban Sci. 2016, 20, 260-284. [CrossRef]

40. Barykin, S.Y.; Kapustina, I.V.; Kirillova, T.V.; Yadykin, V.K.; Konnikov, Y.A. Economics of digital ecosystems. J. Open Innov. Technol. Mark. Complex. 2020, 6, 124. [CrossRef]

41. Lerro, A.; Schiuma, G. Editorial: Knowledge-based dynamics for local development-A position paper. Knowl. Based Dev. 2011, 2, 1-15. [CrossRef]

42. Tao, H.J.A.Z. Research on network of networks theory. In Proceedings of the 2015 IEEE 12th International Conference on Ubiquitous Intelligence and Computing, Beijing, China, 10-14 August 2015.

43. Fichter, K. Innovation communities: The role of networks of promotors in open innovation. RED Manag. 2009, 39, 357-371.

44. De Solà-Morales, M.; Ibelings, H.; Frampton, K. De Cosas Urbanas; Editorial Gustavo Gili: Barcelona, Spain, 2008.

45. Hooghduyn, R. Urban Acupuncture Revitalizing Urban Areas By Small Scale Interventions; Blekinge Institute of Technology: Karlskrona, Sweden, 2014.

46. Veeckman, C.; van der Graaf, S. The city as living laboratory: Empowering citizens with the citadel toolkit. TIM Rev. 2015, 5, 6-17. [CrossRef]

47. Sandulli, F.D.; Ferraris, A.; Bresciani, S. How to select the right public partner in smart city projects. RED Manag. 2017, 47, 607-619.

48. Freeman, R.E. Strategic Management: A Stakeholder Approach; Cambridge University Press: Cambridge, UK, 2010.

49. Guertler, M.R.; Wiedemann, F.; Lindemann, U. The relevance of stakeholder analysis for open innovation. In Proceedings of the R\&D Management Conference, Pisa, Italy, 23-26 June 2015.

50. Ballejos, L.C.; Montagna, J.M. Method for stakeholder identification in interorganizational environments. Requir. Eng. 2008, 13, 281-297. [CrossRef]

51. Gürtler, M.R.; Lindemann, U. Situative open innovation-A model for selecting the right external actors and involving them in an efficient way. In Proceedings of the 19th International Conference on Engineering Design (ICED13), Seoul, Korea, 19-22 August 2013; pp. 259-268.

52. Frooman, J. The issue network: Reshaping the stakeholder model. Can. J. Adm. Sci. 2010, 27, 161-173. [CrossRef]

53. Laurent, B. Innovation for Whom? City Experiments and the Redefinition of Urban Democracy; Springer: Singapore, 2019.

54. Ahern, J.; Cilliers, S.; Niemelä, J. The concept of ecosystem services in adaptive urban planning and design: A framework for supporting innovation. Landsc. Urban Plan. 2014, 1525, 254-259. [CrossRef]

55. Fisher, K.; Yefimova, K.; Ann, B. Adapting design thinking and cultural probes to the experiences of immigrant youth: Uncovering the roles of visual media and music in ict wayfaring. In Proceedings of the $2016 \mathrm{CHI}$ Conference Extended Abstracts on Human Factors in Computing Systems, San Jose, CA, USA, 7-12 May 2016; pp. 859-871.

56. Reason, P.; Bradbury, H. Handbook of Action Research: Participative Inquiry and Practice; Sage Publications: Newbury Park, CA, USA, 2001.

57. Baldwin-Philippi, J.; Gordon, E.; Osgood, C.; Jacob, N. Design action research with government: A guidebook. Available online: http:/ / engagementgamelab.org/pdfs / darg (accessed on 9 March 2014).

58. Thoring, K.; Müller, R.M. Understanding design thinking: A process model based on method engineering. In Proceedings of the 13th International Conference on Engineering and Product Design Education, London, UK, 8-9 September 2011 ; pp. 493-498.

59. Brown, T.; Wyatt, J. Design thinking for social innovation. Dev. Outreach 2010, 12, 29-43. [CrossRef]

60. Yin, R.K. Case Study Research: Design and Methods; SAGE Publications: Thousand Oaks, CA, USA, 2009.

61. Aspers, P. Empirical phenomenology: A qualitative research approach (the cologne seminars). Indo-Pac. J. Phenomenol. 2009, 9, 1-12. [CrossRef]

62. Antons, D.; Piller, F.T. Opening the black box of "not invented here": Attitudes, decision biases, and behavioral consequences. Acad. Manag. Perspect. 2015, 29, 193-217. [CrossRef]

63. Cohen, W.M.; Levinthal, D.A. Absorptive capacity: A new perspective on learning and innovation. Spec. Issue Technol. Organ. Innov. 1990, 35, 128-152. [CrossRef]

64. Yun, J.J. How do we conquer the growth limits of capitalism? Schumpeterian dynamics of open innovation. J. Open Innov. Technol. Mark. Complex. 2015, 1. [CrossRef] 